\title{
Kemampuan Pemecahan Masalah Matematika Ditinjau dari Kemampuan Awal Matematika dan Perbedaan Gender
}

\author{
Erni Apriani ${ }^{1, a}$, Djadir $^{1}$, dan Asdar ${ }^{1}$ \\ ${ }^{1}$ Jurusan Matematika, Fakultas Matematika dan Ilmu Pengetahuan Alam, Universitas Negeri \\ Makassar, 90224 \\ a)ernimath@gmail.com
}

\begin{abstract}
Abstrak. Penelitian ini merupakan penelitian deskriptif yang bersifat kualitatif yang bertujuan untuk mendeskripsikan kemampuan pemecahan masalah matematis ditinjau dari kemampuan awal matematika dan perbedaan gender. Subjek penelitian ini adalah enam orang siswa Keenam siswa dipilih berdasarkan nilai Tes Kemampuan Matematika yang terbagi dalam kategori tinggi, sedang, dan rendah dengan dua orang masing-masing satu laki-laki dan satu perempuan yang mewakili tiap tingkatan kemampuan matematika pada materi SPLDV dengan mengambil nilai tertiggi dari tiap kategori kemampuan. Keenam subjek diberikan TesKemampuan Pemecahan Masalah Matematika I dan TesKemampuan Pemecahan Masalah Matematika II dalam waktu yang berbeda. Teknik analisis data menggunakan analisis kualitatif.Hasil dari penelitian ini menunjukkan bahwa: (1) Indikator menyebutkan hal-hal yang diketahui dan ditanyakan dimiliki oleh semua subjek, (2) Indikatormembuat rencanapenyelesaian masalah dari hal-halyang diketahui untukpemecahan masalahdimiliki oleh semua subjek, (3) Indikator melaksanakanpemecahan masalah melaluirencana yang telah dibuat dimiliki oleh semua subjek, (4) Indikator melakukan pemeriksaan kembali terhadapjawaban yang sudah adadimiliki oleh semua subjek. Kata kunci: penelitian kualitatif, kemampuan pemecahan masalah matematis, kemampuan awal matematika, perbedaan gender, sistem persamaan linear dua variabel
\end{abstract}

\footnotetext{
Abstact. This research is a qualitative descriptive research that aims to describe the ability of problem solving mathematically viewed from the early ability of mathematics and gender differences. The subjects of this study were six students. The six students were selected based on the Mathematics Ability test scores divided into high, medium, and low categories with two men each and one woman representing each level of math skills on SPLDV material by taking the highest grades from each capability category. The six subjects were given the Mathematical Problem Solving Ability Test I and the Mathematics Problem Solving Ability Test II at different times. Data analysis techniques using qualitative analysis. The results of this study indicate that: (1) Indicators mention things that are known and questioned by all subjects, (2) Indicators to make problem-solving plans from things known for problem solving are shared by all subjects, (3) Indicators carry out problem solving through a plan that has been made owned by all subjects, (4) Indicators of re-examination of existing answers owned by all subjects.

Keywords: Qualitative research, mathematical problem solving skills, early math ability, gender differences, two-variable linear equations system
} 


\section{PENDAHULUAN}

Rendahnya nilai matematika siswa ditinjau dari lima aspek kemampuan matematika yang dirumuskan oleh NCTM (1995) yaitu kemampuan pemecahan masalah matematika, komunikasi matematika, penalaran matematika, representasi dan koneksi matematik. Pengelompokan ini sejalan dengan tutuntutan kemampuan yang disarankan pemerintah melalui kurikulum pembelajaran matematika tahun 2006 yang menjadi acuan penilaian secara nasional.Namun dalam penelitian ini hanya membahas pada kemampuan pemecahan masalah.siswa.

Menurut NCTM (2000) bahwa kemampuan pemecahan masalah bukanlah sekedar tujuan dari belajar matematika tetapi juga merupakan alat utama untuk melakukan atau bekerja matematik. Suryadi (2000) juga menyatakan bahwa kemampuan pemecahan masalah merupakan kegiatan yang sangat penting dalam pembelajaran matematika. Hal senada juga dikemukakan oleh Sagala (2009) bahwa pemecahan masalah dalam proses pembelajaran sangat penting, karena selain para siswa mencoba menjawab pertanyaan atau memecahkan masalah, mereka juga termotivasi untuk bekerja keras. Diperkuat (Setiawan, 2008) menyatakan pemecahan masalah merupakan suatu hal yang sangat esensial didalam pengajaran matematika, sebab: (1) siswa menjadi terampil menyeleksi informasi yang relefan, kemudian menganalisanya dan akhirnya meneliti hasilnaya, (2) kepuasan intelektual akan timbul dari dalam, (3) potensi intelektual siswa meningkat.

Dalam pemecahan masalah siswa didorong dan diberi kesempatan seluas-luasnya untuk berinisisatif dan berpikir sistematis dalam menghadapi suatu masalah dengan menerapkan pengetahuan yang didapat sebelumnya.Polya menggambarkan kemampuan pemecahan masalah yang harus dibangun siswa meliputi kemampuan siswa memahami masalah, merencanakan penyelesaian, menyelesaikan masalah sesuai dengan rencana, dan memeriksa kembali prosedur hasil penyelesaian.

Pemecahan masalah memegang peran penting dan perlu ditingkatkan dalam pembelajaran.Akan tetapi fakta dilapangan menunjukkan bahwa kemampuan pemecahan masalah siswa masih rendah. Setiawan (2008) mengungkapkan didalam pembelajaran matematika siswa tidak dibiasakan unuk memecahkan permasalahan matematika yang membutuhkan rencana, strategi, dan mengeksplorasi kemampuan menggenaralisasi dan penyelesaian masalahnya.

Setiawan (2008) juga menyebutkan bahwa kemampuan siswa Indonesia dalam pemecahan masalah hanya $25 \%$ dibandigkan dengan negara-negara sperti Singapura, Hongkong, Taiwan, dan Jepang yang sudah diatas $75 \%$. Ketidak mampuan siswa menyelesaikan masalah seperti diatas dipengaruhi oleh rendahnya kemampuan pemecahan masalah siswa.Karena itu kemampuan pemecahan masalah dalam matematika perlu dilatihkan dan dibiasakan kepada siswa.Kemampuan ini diperlukan siswa sebagai bekal dalam memecahkan masalah matematika dan masalah yang ditemukan dalam kehidupan sehari-hari.

Salah satu faktor internal yang mempengaruhi prestasi belajar siswa dapat disesebabkan kemampuan awal yang dimiliki siswa. Kemampuan awal siswa akan berpengaruh pada proses pembelajaran karena kemampuan awal siswa merupakan prasyarat awal yang harus dimiiki siswa agar proses pembelajaran yang dilakukan siswa dapat berjalan dengan baik. Setiap siswa mempunyai kemampuan awal yang berlainan.Hal ini perlu mendapatkan perhatian guru sebelum melaksanakan pembelajaran.Perbedaan individu dapat mempengaruhi tingkat penguasaan materi bahan pelajaran antara masing-masing siswa. Meskipun belum tentu siswa yang kemampuan awalnya tinggi dapat lebih berhasil mencapai prestasi dari pada siswa yang lain.

Selain dilihat dari aspek kemampuan awal matematika siswa, diperhatikan juga aspek perbedaan gender. Perbedaan gender sudah menjadi sorotan sejak zaman dahulu. Perbedaan jenis kelamin tidak lagi hanya berkaitan dengan masalah biologis saja tetapi kemudian berkembang menjadi perbedaan kemampuan antara laki-laki dan perempuan.Hal ini menunjukkan sebagai perbedaan gender. 
Menurut Nafi'an (2011) perbedaan gender bukan hanya berakibat pada perbedaan kemampuan dalam matematika, tetapi cara memperoleh pengetahuan matematika juga terkait dengan perbedaan gender. Nafi'an(2011) menyatakan "Gender, social, and cultural dimensions are very powerfully interacting in conceptualization of mathematics education, ...". Berdasarkan pendapat Keitel bahwa gender, sosial, dan budaya berpengaruh pada pembelajaran matematika.

Menurut American Psychological Association (Science Daily, 6 Januari 2010) (Nafi'an, 2011) mengemukakan berdasarkan analisis terbaru dari penelitian internasional kemampuan perempuan di seluruh dunia dalam matematika tidak lebih buruk daripada kemampuan laki-laki meskipun laki-laki memiliki kepercayaan diri yang lebih dari perempuan dalam matematika, dan perempuan-perempuan dari negara dimana kesamaan gender telah diakui menunjukkan kemampuan yang lebih baik dalam tes matematika.

Oleh karena itu, penelitian ini mengkajitentang kemampuan pemecahan masalah matematika yang ditinjau dari kemampuan awal matematika dan perbedaan gender. Penelitian ini bertujuan mendeskripsikan kemampuan pemecahan masalah matematis siswa ditinjau dari kemampuan awal matematika dan gender siswa.

\section{METODE PENELITIAN}

Penelitian ini merupakan penelitian kualitatif dengan pendekatan deskriptif. Subjek dipilih sebanyak 6 (enam) orang dengan masing-masing 2 (dua) orang yaitu laki-laki dan perempuan dengan kategori kemampuan matematika tinggi, kemampuan matematika sedang, dan kemampuan matematika rendah. Subjek dipilih dengan diberikan tes kemampuan awal matematika pada materi SPLDV.

Pengumpulan data selanjutnya dilakukan dengan tes kemampuan pemecahan masalah matematika kemudian diberikan wawancara berbasis tugas. Wawancara dilakukan untuk menelusuri kemampuan pemecahan masalah matematika berdasarkan tes kemampuan pemecahan masalah yang telah diberikan sebelumnya. Kemampuan pemecahan masalah subjek penelitian dipelajari melalui interpretasi atau representasi yang diberikan subjek dalam menjawab pertanyaan-pertanyaan pewawancara. Wawancara tersebut direkam.

Teknik analisis data dilakukan dengan mereduksi data, mendisplay data (menyajikan data), kemudian menarik kesimpulan.

\section{HASIL DAN PEMBAHASAN}

Berdasarkan data yang diperoleh dari wawancara berbasis tugas diketahui bahwa kemampuan pemecahan masalah memiliki empat indikator menurut Polya yaitu (1) menyebutkan hal-hal yang diketahui dan ditanyakan, (2) membuat rencana penyelesaian masalah dari hal-hal yang diketahui untuk pemecahan masalah, (3) melaksanakan pemecahan masalah melalui rencana yang telah dibuat dan (4) melakukan pemeriksaan kembali jawaban yang sudah ada.

Kemampuan pemecahan masalah matematika subjek berkemampuan SPLDV tinggi laki-laki memuat tiap indikator yaitu subjek menuliskan yang diketahui dengan membuat pemisalan dan membuat pola matematikanya, kemudian melakukan penyelesaian dengan metode subtitusi, terakhir melakukan pemeriksaan kembali terhadap jawaban yang telah ia peroleh.

Kemampuan pemecahan masalah matematika subjek berkemampuan SPLDV tinggi perempuan memuat tiap indikator yaitu subjek menuliskan yang diketahui dengan membuat pemisalan dan membuat pola matematikanya, kemudian melakukan penyelesaian dengan metode eliminasi dan subtitusi, terakhir melakukan pemeriksaan kembali terhadap jawaban yang telah ia peroleh.

Kemampuan pemecahan masalah matematika subjek berkemampuan SPLDV sedang laki-laki memuat tiap indikator yaitu subjek menuliskan yang diketahui dengan membuat pemisalan dan 
membuat pola matematikanya, kemudian melakukan penyelesaian dengan metode grafik, terakhir melakukan pemeriksaan kembali terhadap jawaban yang telah ia peroleh.Namun pada pembuatan pola matematika, subjek merasa kesulitan sehingga membutuhkan waktu yang lama dalam pengerjaan.

Kemampuan pemecahan masalah matematika subjek berkemampuan SPLDV sedang perempuan memuat tiapindikator yaitu subjek menuliskan yang diketahui dengan membuat pemisalan dan membuat pola matematikanya, kemudian melakukan penyelesaian dengan metode eliminasi, terakhir melakukan pemeriksaan kembali terhadap jawaban yang telah ia peroleh.

Kemampuan pemecahan masalah matematika subjek berkemampuan SPLDV rendah laki-laki memuat tiap indikator yaitu subjek menuliskan yang diketahui dengan membuat pemisalan dan membuat pola matematikanya, kemudian melakukan penyelesaian dengan metode subtitusi, terakhir melakukan pemeriksaan kembali terhadap jawaban yang telah ia peroleh.Namun subjek kesulitan dalam pembuatan pola matematikanya.

Kemampuan pemecahan masalah matematika subjek berkemampuan SPLDV rendah perempuan memuat tiap indikator yaitu subjek menuliskan yang diketahui dengan membuat pemisalan dan membuat pola matematikanya, kemudian melakukan penyelesaian dengan metode eliminasi dan subtitusi, terakhir melakukan pemeriksaan kembali terhadap jawaban yang telah ia peroleh.

Adapun data yang dibahas adalah data yang valid dari hasil reduksi wawancara. Data valid itu diperoleh dengan melihat kekonsistenan data dari wawancara pertama dan wawancara kedua.

\section{KESIMPULAN}

Semua subjek memenuhi kemampuan pemecahan masalah matematika pada materi SPLDV dengan memperhatikan tahap-tahap yang telah dikemukakan dalam menemukan jawaban diantaranya tahap pemecahan masalah Polya, yaitu : memahami masalah, merencanakan penyelesaian, menyeleaikan masalah sesuai rencana, dan melakukan pengecekan kembali terhadap semua langkah yang telah dikerjakan, dengan indicator masing-masing, menyebutkan hal-hal yang diketahui dan ditanyakan, membuat rencana penyelesaian masalah dari hal-hal yang diketahui untuk pemecahan masalah, melaksanakan pemecahan masalah melalui rencana yang telah dibuat, melakukan pemeriksaan kembali terhadap jawaban yang sudah ada. Namun, subjek laki-laki cenderung kesulitan dalam memahami soal an pembuatan model matematika dibanding siswa perempuan yang mempunyai usaha lebih dalam pemahaman soal dengan melakukan pemisalan dari soal yang telah diberikan.

Kajian dalam penelitian ini masih terbatas pada kemampuan pemecahan masalah matematika siswa pada materi SPLDV ditinjau dari kemampuan awal matematika dan gender. Oleh karena itu peneliti meyarankan apabila hendak melaksanakan penelitian ulang maka dapat ditinjau ari aspek lain an memperluas cakupan materinya

\section{DAFTAR PUSTAKA}

Nafi'an. (2011). Seminar Nasional Matematika dan Pendidikan Matematika. Kemampuan Siswa dalam Menyelesaikan Soal Cerita ditinjau dari Gender Di Sekolah Dasar. Yogyakarta: Universitas Negeri Yogyakarta.

NCTM. (1995). Curriculum And Evaluation Standards For School Mathematics. The National Council of Teachers of Mathematics, Inc. 
NCTM. (2000). Principles and Standards for School Mathematics Teacher. The National Council of Teachers of Mathematics, Inc.

Sagala. (2009). Kemampuan Profesional Guru dan Tenaga Kependidikan. Bandung: Alfabeta

Setiawan. (2008). Prinsip-Prinsip Penilaian Pembelajaran Matematika SMA. Yogyakarta: Departemen Pendidikan Nasional

Suryadi. (2008). Pemecahan Masalah dalam Matematika dan Matematika Eksploratif. Bandung: UPI 